\title{
STUDI ANALISIS KUALITAS AIR DI DAERAH ALIRAN SUNGAI PAKERISAN PROVINSI BALI
}

\author{
Ni Ketut Asrini ${ }^{\left.{ }^{*}\right)}$, I Wayan Sandi Adnyana $^{2)}$, I Nyoman Rai $^{2)}$ \\ ${ }^{1)}$ Dinas Kesehatan Kabupaten Klungkung \\ ${ }^{2}$ Fakultas Pertanian Universitas udayana \\ * Email: ketutasrini1970@gmail.com
}

\begin{abstract}
STUDY OF WATER QUALITY ANALYSIS IN PAKERISAN WATERSHED, BALI PROVINCE

Pakerisan watershed is used by the people for various purposes to meet the daily needs for water and it is also for irrigation water. The aim of research was to determine the water quality related to human activities and the pollution index. Water sampling was conducted in the nine sample points i.e. upstream of two sample points, in the middle of four sample points, and in the downstream of three sample points. Sampling was done by purposive sampling. Determination of water quality wascarried out by comparing the measured data of each parameter of water with the value of quality standards based on the Bali Governor Regulation Number 08 of 2007, while the definition of the status of water quality was done by the pollution index method.The results showed that the activities that affect the water quality physically, chemically and biologically at the upstream to downstream are farming activities, settlements, tourism and trade. In the upstream showed no parameters that exceeded the quality standards, the variables of BOD, COD, phosphate, fecal coli and total coli exceeded the quality standards and in the downstream, the BOD, fosfat and fecal coli exceeded the quality standards. The pollution index found in the upstream region good condition, whereas in the middle was classified as heavily polluted until the downstream was lightly polluted.
\end{abstract}

Keywords: watershed, water quality, pollution index

\section{PENDAHULUAN}

Kualitas air sungai dipengaruhi oleh kualitas pasokan air yang berasal dari daerah tangkapannya, sedangkan kualitas pasokan air dari daerah tangkapan berkaitan dengan aktivitas manusia yang ada di dalamnya (Wiwoho, 2005). Saat ini masalah utama yang dihadapi adalah air yang ada dipermukaan sering tercemar sehingga mengurangi kualitas air. Penurunan kualitas air akan menurunkan daya guna, hasil guna, produktivitas, daya dukung dan daya tampung dari sumber daya air yang pada akhirnya menurunkan kekayaan sumber daya alam. Untuk mendapat air sesuai standar tertentu saat ini menjadi barang yang mahal, karena air sudah banyak tercemar oleh bermacammacam limbah dari kegiatan manusia sehingga secara kualitas sumber daya air telah mengalami penurunan.

Hasil pengujian Unit Pelayanan Teknis Laboratorium Lingkungan BLH Provinsi Bali (2013), menyatakan sepuluh sungai yakni Tukad Badung, Tukad Mati, Tukad Ayung, Tukad Jinah, Tukad Pakerisan, Tukad Unda, Tukad Sangsang, Tukad Saba, Tukad Bubuh, dan Tukad Sungi masih menjadi tempat untuk mandi dan kebutuhan lain di Bali telah positif tercemar berbagai jenis limbah sehingga telah mengalami penurunan kualitas. Kesepuluh sungai terindikasi mengandung Biologycal Oxygen Demand (BOD) sebesar $4 \mathrm{mg} / \mathrm{l}$, Chemical Oxygen Demand (COD) sebesar $11 \mathrm{mg} / \mathrm{l}$ yang berada diatas ambang batas baku mutu air kelas I, lapisan minyak, fosfat $(0,27 \mathrm{mg} / \mathrm{l})$ dan lainnya. Menurut Rai et al. (2015) sumber utama pencemaran air di Bali adalah limbah domestik, limbah industri/perusahaan, limbah pertanian, limbah pariwisata dan perdagangan.

Berdasarkan sepuluh sungai yang tercemar, salah satu yang merupakan DAS yang dilestarikan adalah DAS Pakerisan yang dimanfaatkan oleh masyarakat untuk berbagai keperluan seperti untuk memenuhi kebutuhan akan air sehari-hari dan juga dimanfaatkan untuk air irigasi. Sungai Pakerisan adalah salah satu dari 162 sungai di Bali yang secara kosmologis mengalir dari perbukitan Kintamani. Sungai yang memiliki luas DAS lebih kurang 29,88 $\mathrm{km}^{2}$ dengan panjang sungai $34,50 \mathrm{~km}$ ini, sepanjang alirannya terdapat situs Tirtha Empul, Candi Yeh Mangening, Candi Tebing Gunung Kawi,Campuhan, Tampak Siring, Candi Tebing Kerobokan, CandiPengukur-ukuran serta Candi Tebing Tegal Linggah.

Tujuan dari penelitian ini adalah untuk menentukan kualitas air Sungai Pakerisan berkaitan dengan aktivitas manusia disekitarnya dan menentukan indeks pencemaran air Sungai 
Pakerisan. Penelitian ini diharapkan dapat memberikan kontribusi dalam perbendaharaan tulisan ilmiah bagi dunia akademik khususnya bagi analisis kualitas air dan alternatif penelitian lebihlanjut dan dapat dijadikan bahan pertimbangan pemerintah daerah dan penggiat lingkungan untuk melakukan kebijakan serta langkah yang strategis dalam melestarikan biota yang hidup didalamnya, serta perlindungan sumber daya air di KabupatenGianyar.

\section{METODOLOGI}

Penelitian ini termasuk jenis penelitian observasional melalui pengukuran lapangan dan pengujian laboratorium untuk menentukan sumbersumber pencemaran, kualitas air dan indeks pencemaran.

Lokasi penelitian dilakukan di Daerah aliran Sungai Pakerisan yang mempunyai daerah aliran (DAS) seluas lebih kurang 29,88 km² dengan panjang sungai $34,50 \mathrm{~km}$. Pengambilan sampel kualitas air dilakukan di titik sampel hulu, tengah dan hilir. Pengambilan sampel air dilaksanakan pada bulan April 2016.

Pengukuran kualitas air Sungai Pakerisan meliputi kualitas fisik (temparatur dan TSS/ kekeruhan dan TDS); kimia (pH, BOD5, DO, COD, dan total fosfat) dan mikrobiologi (fecal coliform dan total coliform) dengan mempergunakan baku mutu sebagai pembanding untuk kelayakan kualitas parameter sungai yaitu baku mutu air berdasarkan Peraturan Gubernur Bali No. 08 Tahun 2007. Pengukuran indeks pencemaran untuk mengetahui status mutuair. Dan identifikasi terhadap sumber pencemar yang menyebabkan terjadinya penurunan kualitas air.

Pengambilan sampel kualitas air dilakukan pada sembilan lokasi. Penentuan sampel tersebut berdasarkan di daerah hulu merupakan daerah yang aktivitas manusia kurang, pertanian dan daerah yang disucikan. Di daerah tengah dan hilir penentuan sampel berdasarkan adanya aktivitas manusia, pemukiman dan industri yang mempengaruhi kualitas air sungai.Jumlah titik sampel di hulu adalah dua, di tengah empat titik sampeldan di hilir tiga titik sampel.

Pengumpulan data variabel tingkat kualitas air yang akan diukur meliputi fisik: suhu, TSS/ kekeruhan danTDS, kimia: $\mathrm{pH}, \mathrm{DO}, \mathrm{BOD}, \mathrm{COD}$, dan totalfosfat, biologi : fecal coliform dan totalcoliform. Pengambilan parameter di atas dilakukan secara in situ dan ex situ.Variabel indeks pencemaran yang diukur pada DAS Pakerisan adalah evaluasi terhadap nilai Indeks Pencemaran (PI) adalah:0d" PIjd"1,0 dinyatakan kondisi baik (memenuhi bakumutu), $0<$ PIjd"5, tercemar ringan, 5,0 < PIj d"10, tercemar sedang, $\mathrm{PIj}>10$,0tercemar berat.
Instrumen penelitian yang digunakan terdiri dariseperangkat alat pengambilan sampel kualitas air, meteran, botol gelap dari kaca, botol plastik, stopwacth, thermometer, $\mathrm{pH}$ meter, bahan pengawet, alat dokumentasi, komputer, peta sungai dan wadah sampel air.

Data parameter kualitas air yang diperoleh berdasarkan analisis laboratorium dibandingkan dengan nilai baku mutu berdasarkan Peraturan Gubernur Bali No. 08 Tahun 2007 tentang Baku Mutu Lingkungan Hidup dan Kriteria Baku Kerusakan Lingkungan Hidup. Penentuan status mutu air dengan menggunakan metode Indeks Pencemaran. Selanjutnya dianalisis sumber-sumber pencemarannya.

\section{HASIL DAN PEMBAHASAN}

\subsection{Kualitas Fisik}

\subsubsection{Suhu}

Berdasarkan hasil analisis parameter kualitas air daerah hulu, tengah dan hilir menunjukkan bahwa parametersuhu air hasil pengukuran secara insitu pada 9 lokasi diperoleh suhu di daerah hulu (Q1 banjar Sareseda) hingga hilir (Q9 banjar Medahan) berkisar antara $25,4^{\circ} \mathrm{C}$ sampai $28,5^{\circ} \mathrm{C}$. Suhu ini berada dalam standar baku mutu Peraturan Gubernur Bali No.08 Tahun 2007 tentang Baku Mutu Lingkungan Hidup dan Kriteria Baku Kerusakan lingkungan Hidup yaitu pada deviasi 3 dari keadaan alamiah. Kondisi kualitas air sungai ditinjau dari parameter suhu masih dalam batas baku mutu air sesuai dengan peruntukan. Suhu air pada penelitian ini sesuai dengan suhu air di lokasi air Tukad Yeh Poh pada daerah hulu yang mencapai $25^{\circ} \mathrm{C}$ sampai $25,2^{\circ} \mathrm{C}$ (Ari Esta et. al., 2016). Suhu air penelitian ini juga hampir sama dengan hasil penelitian kualitas air Tukad Saba yang mencapai rata-ratanya $21,87^{\circ} \mathrm{C}$ $31,50^{\circ} \mathrm{C}$ (Susanti, 2015).

Menurut Effendi (2003), suhu berperan mengendalikan kondisi ekosistem perairan. Peningkatan suhu menyebabkan peningkatan dekomposisi bahan organik oleh mikroba. Kisaran suhu optimum bagi pertumbuhan fitoplankton di perairan adalah $20^{\circ} \mathrm{C}-30^{\circ} \mathrm{C}$. Suhu air sungai Pakerisan masih dapat mendukung dalam hal pertumbuhan fitoplankton. Adanya perbedaan suhu pada DAS Pakerisan dari hulu ke hilir disebabkan oleh perbedaan ketinggian tempat dari permukaan laut, adanya sumber pencemar aktivitas manusia seperti pemukiman, pertanian, peternakanan dan pariwisata seiiring dengan berkurangnya ketinggian ke wilayah hilir.

Penyebaran suhu juga disebabkan oleh arus air dan turbulensi di wilayah hulu, tengah dan hilir berbeda. Intensitas cahaya matahari semakin banyak ke wilayah hilir, pertukaran panas antara air dan 
udara ke hilir lebih besar sehingga terjadi peningkatan suhu.

\subsubsection{Zat tersuspensi (Total SuspendedSolid/ TSS)}

Berdasarkan hasil pemantauan parameter TSS pada setiap lokasi pengamatan menunjukkan terjadinya peningkatan dari hulu Q1 (Banjar Saresede, Desa Tampaksiring) ke hilir Q9 (Banjar Cucukan, Desa Medahan). Konsentrasi TSS mengalami di hulu Q1 (Banjar Saresede) sebesar 1 mg/l, di tengah Q5 (Banjar Tiapi) mencapai sebesar $24 \mathrm{mg} / \mathrm{l}$ dan di hilir Q9 (Banjar Cucukan) sebesar 13 $\mathrm{mg} / \mathrm{l}$. Bila dibandingkan dengan baku mutu kelas I berdasarkan Peraturan Gubernur Bali No.08 Tahun 2007 yaitu sebesar 50 mg/l , maka kondisi kualitas air Sungai Pakerisan bila dilihat dari konsentrasi TSS masih dalam batas baku mutu air sesuaiperuntukannya.

TSS terdiri dari lumpur dan pasir halus serta jasad-jasad renik, yang terutama disebabkan oleh kikisan tanah atau erosi tanah yang terbawa ke badan air (Effendi, 2003). Adanya peningkatan nilai TSS air Sungai Pakerisan di wilayah tengah diindikasikan karena banyaknya alih fungsi lahan menjadi daerah terbangun/pemukiman disekitar aliran Sungai Pakerisan di Banjar Tiapi, terutama adanya pasir, tanah liat yang ada dalam perairan sehingga mempengaruhi regenerasi oksigen secara fotosintesis. Di wilayah hilir terjadi pengendapan karena di wilayah tengah arus air kurang lancar yang tergenang bersama sampah dan limbah yang ada.

\subsubsection{Kekeruhan dan Padatan Terlarut(TDS)}

Konsentrasi kekeruhan air Sungai Pakerisan yang dilakukan di lokasi hulu sebesar 0,8 NTU di lokasi tengah sebesar 16,7 NTU dan di lokasi hilir sebesar 7,6 NTU. Konsentrasi kekeruhan di wilayah tengah tinggi karena padatan tersuspensi seperti pasir, tanah liat, bahan-bahan organik yang dibawa oleh limbah lebih banyak. Semakin tinggi padatan tersuspensi semakin tinggi nilai kekeruhan. Apabila kekeruhan tinggi maka kandungan oksigen akan menurun. Hal ini disebabkan intensitas cahaya matahari masuk kedalam perairan sangat terbatas sehingga fitoplankton tidak dapat melakukan proses fotosintesis untuk menghasilkan oksigen.

Kandungan TDS terendah pada lokasi tengah Q3 (Banjar Tegalsuci, Desa Tampaksiring) sebesar $248 \mathrm{mg} / \mathrm{l}$ dan tertinggi di lokasi hilir Q9 (Banjar Cucukan, Desa Medahan) sebesar $303 \mathrm{mg} / \mathrm{l}$. Bila dibandingkan dengan baku mutu kelas I berdasarkan Peraturan Gubernur Bali No.08 Tahun 2007 yaitu sebesar $1000 \mathrm{mg} / \mathrm{l}$, maka kondisi kualitas air Sungai Pakerisan bila dilihat dari parameter TDS masih dalam batas baku mutu air sesuai peruntukannya. Hasil penelitian ini hampir mirip dengan penelitian Putri, et al. (2014) diperoleh nilai rata-rata TDS tersuspensi pada Sungai Siak Pekanbaru adalah 70,4 mg/L yang tergolong sebagai air lunak (soft water).

\subsection{Kualitas Kimia}

\subsubsection{Derajat keasaman $(\mathrm{pH})$}

Nilai pH air Sungai Pakerisan pada lokasi hulu Q1(Banjar Saresede) sampai lokasi hilir Q9 (Banjar Cucukan) diperoleh nilai antara 7-8. Nilai $\mathrm{pH}$ tersebut masih dalam batas baku mutu air kelas I yaitu berada dalam nilai 6-9. Dibandingkan dengan hasil Badan Lingkungan Hidup Propinsi Bali tahun 2013 nilai pH 6-7. Menurut Kristanto (2002) derajat keasaman $(\mathrm{pH})$ sangat erat hubungannya dengan kandungan logam berat yang terdapat di dalam sungai semakin banyak bahan pencemar (kandungan logam berat) yang berada di dalam sungai maka akan mengakibatkanrendahnya nilai $(\mathrm{pH})$ yang membuat kesadahan air yang bersifat asam, air yang digolongkan asam karena bersifat bikarbonat dalam air. Derajat keasaman $(\mathrm{pH})$ suatu perairan juga dipengaruhi oleh faktor alami dan manusia.

Peningkatan nilai $\mathrm{pH}$ pada lokasi Q4 (Banjar Bukit), lokasi Q5 (Banjar Tiapi), lokasi Q6 (Banjar Sema) mencapai 8 dikarenakan adanya aktivitas pembuangan limbah organik yang bersumber dari limbah domestik maupun limbah yang berasal dari aktivitas pertanian di sekitar sungai yang masuk ke aliran Sungai Pakerisan. Menurut Yuliastuti (2011) fluktuasi nilai pH dipengaruhi oleh adanya buangan limbah organik dan anorganik ke sungai. Air normal yang memenuhi syarat untuk suatu kehidupan mempunyai $\mathrm{pH}$ sekitar 6,5-7,5 (Wardhana, 2004). Nilai $\mathrm{pH}$ air yang tidak tercemar biasanya mendekati netral $(\mathrm{pH}$ 7) dan memenuhi kehidupan hampir semua organisme air (Suharto, 2011).

\subsubsection{Konsentrasi BOD}

Konsentrasi BOD air Sungai Pakerisan diperoleh nilai konsentrasi BOD paling tinggi pada lokasi tengah Q6 (Banjar Sema) yaitu 5,29 mg/l dan paling rendah pada lokasi hulu Q1(Banjar Saresede) yaitu $0,32 \mathrm{mg} / \mathrm{l}$. BOD adalah jumlah oksigen terlarut yang dibutuhkan oleh bakteri pengurai untuk menguraikan bahan pencemar organik dalam air. Makin besar kosentrasi BOD suatu perairan, menunjukan konsentrasi bahan organik di dalam air juga tinggi (Yudo, 2010).

Hasil pemantauan parameter BOD pada lokasi Q6 sampai Q9 dibandingkan dengan baku mutu air kelas I melebihi ambang batas yang ditentukan yaitu lebih dari $2 \mathrm{mg} / \mathrm{l}$. Peningkatan BOD berpengaruh terhadap konsentrasi oksigen terlarut berkurang. Pada lokasi hulu sampai tengah masih dibawah ambang batas. Bila dibandingkan hasil dari Badan Lingkungan Hidup tahun 2013 diperoleh di wilayah hulu sebesar $0,92 \mathrm{mg} / \mathrm{l}$, di wilayah tengah sebesar 
1,99 mg/l dan di wilayah hilir sebesar 4,06 mg/l. Makin besar kadar BOD nya, maka merupakan indikasi bahwa perairan tersebut telah tercemar. Kadar BOD dalam air yang tingkat pencemarannya masih rendah dan dapat dikategorikan sebagai perairan yang baik berkisar 0-10 ppm (Salmin, 2005). Naiknya angka BOD dapat berasal dari bahan- bahan organik yang berasal dari limbah domestik dan limbah lainnya (Rahayu dan Tontowi, 2009). Nilai BOD yang tinggi karena adanya pembuangan limbah dari pemukiman ke sungai dan dari lahan pertanian (Anhwange et al.,2012).

Hasil pengukuran konsentrasi BOD diperoleh paling rendah diperoleh pada lokasi hulu (Banjar Saresede) dan Q2 (Banjar Penaka) sebesar 0,3 mg/ liter dan paling tinggi diperoleh pada lokasi tengah Q6 (Banjar Sema) yaitu sebesar 5,29 mg/liter. Hasil pengukuran menunjukkan bahwa konsentrasi BOD pada lokasi hulu Q1 hingga Q5 masih di bawah baku mutu air yaitu $2 \mathrm{mg} /$ liter, sedangkan pada lokasi tengah Q6 hingga hilir Q9 terjadi peningkatan konsentrasi BOD hingga di atas baku mutu air. Hal ini menunjukkan tingkat pencemarnya lebih tinggi dibandingkan dengan lokasi di (Q1-Q5). Peningkatan pencemaran ini disebabkan adanya pemukiman, pertanian, industri usaha tahu yang membuang limbah ke sungai.

\subsubsection{Kebutuhan Oksigen Kimiawi (Chemical Oxygen Demand/COD)}

Konsentrasi COD air Sungai Pakerisan yang dilakukan pada wilayah hulu Q1 (Banjar Saresede) hingga wilayah tengah sebesar $6 \mathrm{mg} / \mathrm{l}-13 \mathrm{mg} / \mathrm{l}$ dan wilayah hilir Q7 (Banjar Bona Kaja) sampai Q9 (Banjar Cucukan) sebesar 8-10 mg/l. Bila dibandingkan dengan hasil dari Badan Lingkungan Hidup Propinsi Bali tahun 2013 wilayah hulu COD sebesar $3 \mathrm{mg} / \mathrm{l}$, wilayah tengah sebesar $5 \mathrm{mg} / \mathrm{l}$ dan hilir sebesar $11 \mathrm{mg} / \mathrm{l}$ (diatas ambang baku mutu air kelas I yaitu $10 \mathrm{mg} / \mathrm{l}$. Tingginya COD di wilayah tengah terutama di Banjar Seme karena adanya pemukiman, perdagangan dan industri pembuatan tahu yang membuang limbahnya ke sungai.Air sungai menjadi sangat kotor dan adanya sampah.COD adalah banyaknya oksigen yang dibutuhkan untuk mengoksidasi bahan-bahan organik secara kimia (Yudo, 2010).

Banyaknya konsentrasi BOD dan COD yang di wilayah tengah meningkat di atas ambang baku mutu air kelas I, sedangkan konsentrasi DO semakin kehulu semakin tinggi menyebabkan menurunnya kadar oksigen terlarut dalam air di wilayah hilir. Sehingga akan mengakibatkan kehidupan dalam air di wilayah tengah yang membutuhkan oksigen terganggu serta mengurangi perkembangannya. Selain itu kematian dapat pula disebabkan adanya zat beracun yang juga menyebabkan kerusakan pada tanaman dan tumbuhan air. Akibat matinya bakteribakteri, maka proses penjernihan air secara alamiah yang seharusnya terjadi pada air limbah juga terhambat.

\subsubsection{Oksigen terlarut (Dissolved Oxygen/DO)}

Hasil pemantauan konsentrasi oksigen terlarut (DO) yang dilakukan di wilayah hulu sebesar 6,58 $\mathrm{mg} / \mathrm{l}$, di wilayah tengah sebesar $6,29 \mathrm{mg} / \mathrm{l}$ dan di wilayah hilir sebesar $5,25 \mathrm{mg} / \mathrm{l}$. Hasil pengujian Badan Lingkungan Hidup tahun 2013 diperoleh nilai DO di hulu sebesar $7,52 \mathrm{mg} / \mathrm{l}$, di wilayah tengah sebesar 7,01 dan di wilayah hilir sebesar 7,36 mg/l.

Parameter oksigen terlarut dapat digunakan sebagai indikator tingkat kesegaran air (Sutriati, 2011). Oksigen memegang peranan penting sebagai indikator kualitas perairan, karena oksigen terlarut berperan dalam proses oksidasi dan reduksi bahan organik dan anorganik. Karena proses oksidasi dan reduksi inilah maka peranan oksigen terlarut sangat penting untuk membantu mengurangi beban pencemaran pada perairan secara alami (Salmin, 2005). Suatu perairan dapat dikatakan baik dan mempunyai tingkat pencemaran yang rendah jika kadar oksigen terlarutnya (DO) lebih besar dari 5 $\mathrm{mg} / \mathrm{l}$ (Salmin, 2005), sedangkan konsentrasi oksigen terlarut (DO) pada perairan yang masih alami memiliki nilai DO kurang dari $10 \mathrm{mg} / \mathrm{l}$ (Effendi, 2003).

Aktivitas manusia seperti pertanian dan pembuangan limbah, menyebabkan penurunan kosentrasi oksigen terlarut (Blume et. al., 2010). Perairan dapat dikategorikan sebagai perairan yang baik dan tingkat pencemarannya rendah, jika kadar oksigen terlarutnya $>5 \mathrm{mg} / \mathrm{l}$ (Salmin, 2005). Hal ini menandakan bahwa kualitas air Sungai Pakerisan pada lokasi Q7 (Banjar Bona Kaja) yaitu wilayah hilir hingga lokasi Q9 (Banjar Cucukan) berdasarkan parameter DO memiliki tingkat pencemaran lebih tinggi dari lokasi hulu dan tengah. Semakin ke hilir DO semakin rendah tetapi bila dihubungkan dengan BOD semakin tinggi, karena oksigen yang digunakan untuk mengoksidasi limbah organik lebih banyak.

\subsubsection{Fosfat(PO4)}

Hasil pemantauan parameter pada setiap wilayah menunjukkan fosfat (PO4) dalam air Sungai Pakerisan meningkat dari huludi Banjar Saresede (Q1) ke hilirdi Banjar Cucukan (Q9). Konsentrasi parameter fosfat di Sungai Pakerisan berkisar 0,070,42 mg/l. Dibandingkan dengan baku mutu air kelas I berdasarkan Peraturan Gubernur tahun 2007 yaitu $0,2 \mathrm{mg} / \mathrm{l}$, maka kondisi kualitas air Sungai Pakerisandi wilayah hulu dibawah baku mutu air kelas I, di wilayah tengah di Banjar Sema (Q6) sampai di hilir Banjar Cucukan (Q9) di atas baku mutu air kelas I. Dibandingkan dengan hasil dari Badan Lingkungan Hidup Propinsi Bali tahun 2013 konsentrasi fosfat di wilayah hulu $0,13 \mathrm{mg} / \mathrm{l}$, wilayah tengah sebesar $0,14 \mathrm{mg} / \mathrm{l}$ dan wilayah hilir sebesar $0,27 \mathrm{mg} / \mathrm{l}$. 
Konsentrasi fosfat mengalami peningkatan dari hulu ke hilir, hal ini disebabkan karena petani pada wilayah ini masyarakat sebagai petani lebih banyak menggunakan pupuk buatan (N,P,K) dan pestisida dalam proses pemupukan tanaman yang ditanam sehingga limbah yang dihasilkan masuk ke sungai. Disamping itu limbah industri tahu, loundry, domestik dan MCK yang berasal dari detergen berpengaruh terhadap air sungai sehingga mencemari sungai yang berpengaruh terhadap konsentrasi fosfat di airsungai.Kandungan fosfor total dalam perairan alamiah jarang melebihi $1 \mathrm{mg} /$ liter (Effendi, 2003). Kadar fosfor yang diperkenankan bagi kepentingan air minum adalah $0,2 \mathrm{mg} / \mathrm{l}$ dalam bentuk fosfat $\left(\mathrm{PO}_{4}\right)$.

\subsection{Kualitas Biologi}

\subsubsection{Fecalcoliform}

Konsentrasi fecal coliform yang dilakukan di wilayah hulu Q1(Banjar Saresede) sampai wilayah Q5 (Banjar Tiapi) memenuhi baku mutu air kelas I yang ditetapkan, di wilayah tengah Q6 (Banjar Sema) sampai ke hilir Q9 (Banjar Cucukan) melampaui baku mutu air kelas I sebesar $100 \mathrm{jml} / 100 \mathrm{ml}$. Konsentrasi fecal coliform berkisar antara 2-640 jml/ $100 \mathrm{ml}$.

Air Sungai Pakerisan sebagian telah tercemar oleh fecal coliform. Konsentrasi fecal coliformairsungai Pakerisantelah meningkat sehingga melampaui baku mutu air kelas I yang ditetapkan dari tengah ke hilir. Terdapat peningkatan konsentrasi fecal coliform cukup tinggi di wilayah tengah (Q6) Banjar Sema. Pencemaran ini disebabkan karena air limbah industri, pemukiman sekitarnya, limbah kotoran ternak dan pemanfaatan sungai langsung untuk cuci dan kakus. Hal ini menunjukkan bahwa air Sungai Pakerisan di bagian tengah dan hilir telah tercemar oleh fecalcoliform.

Peningkatan beban pencemar yang berada di Banjar Sema, Desa Bitra mengandung tinja semakin meningkat karena aktivitas peternakan, limbah domestik yang masuk ke badan sungai lebih tinggi karena pemanfaatan sungai langsung untuk cuci dan kakus semakin banyak. Konsentrasi fecal coliformke hilir menurun tetapi masih diatas baku mutu air kelas I. Hal ini disebabkan aktivitas manusia berkurang, pemukiman dan peternakan lebih sedikit. Pada wilayah hilir Q9 (Banjar Cucukan) konsentrasi fecal coliform hampir berada pada batas baku mutu air kelas I karena adanya sumber mata air dan dekat dengan laut. Beberapa jenis penyakit dapat ditularkan oleh bakteri coliform melalui air, terutama penyakit perut seperti tipus, kolera dan disentri (Prihartanto dan Budiman,2007).

\subsubsection{Total Coliforms}

Konsentrasi total coliform air sungai Pakerisan yang dilakukan di wilayah hulu hingga di wilayah hilir yangberkisar antara $30-1100 \mathrm{jml} / 100 \mathrm{ml}$, di hulu Q1 (Banjar Saresede) terendah sebesar 30 jml/100 $\mathrm{ml}$ kemudian meningkat di wilayah tengah Q6 (Banjar Sema) sebesar 1100 jml/100 ml dan menurun di hilir lokasi Q9 (Banjar Cucukan) sebesar 640 jml/ $100 \mathrm{ml}$. Bila dibandingkan dengan hasil penelitian Badan Lingkungan Hidup Propinsi Bali tahun 2013 konsentrasi total coliform wilayah hulu sebesar 30 $\mathrm{jml} / 100 \mathrm{ml}$, tengah sebesar $70 \mathrm{jml} / 100 \mathrm{ml}$ dan hilir sebesar $210 \mathrm{jml} / 100 \mathrm{ml}$.

Terdapat peningkatan konsentrasi total coliform dari hulu ke hilir dengan peningkatan yang tajam di lokasi Q6 (Banjar Sema), bakteri coliform termasuk bakteri yang dapat ditemukan di lingkungan tanah dan air yang telah berpengaruh oleh air permukaan serta limbah pembuangan kotoran manusia dan hewan serta dari hewan dan tanaman yang sudah mati. Tingginya nilai total coliform pada lokasi Banjar Sema diindikasikan berasal dari sampah organik yang dibuang sembarangan di tepi sungai yang membusuk kemudian terbawa ke aliran sungai.Tingginya konsentrasi indikator mikrobiologi fecal coliform dan total coliform di lokasi Q6 (Banjar Sema) dapat dikatakan Sungai Pakerisan telah mengalami pencemaran dari kotoran manusia, hewan ternak dan sampah organik. Bakteri fecal coliform yang mencemari air akan mengganggu kesehatan manusia.

\subsection{Indeks Pencemaran Air SungaiPakerisan}

Penentuan status mutu air pada Sungai Pakerisan didasarkan atas metode indeks pencemaran. Sungai dikatakan tercemar apabila tidak dapat digunakan sesuai dengan peruntukaannya secara normal (Azwir, 2006). Dalam penelitian ini parameter yang digunakan menganalisis status mutu air adalah $\mathrm{pH}$, TSS, DO, BOD, COD, fosfat, fecal coliform dan total coliform yang dibandingkan dengan kriteria mutu air kelas I berdasarkan Peraturan Gubernur Provinsi Bali No. 8 Tahun 2007.

Nilai indeks pencemar masing- masing lokasi pada penelitian ini selengkapnya dapat disajikan pada Gambar 1.

Berdasarkan hasil perhitungan indeks pencemaran (IP) maka dapat diketahui status mutu air sungai Pakerisan dari hulu ke hilir telah mengalami penurunan. Status mutu air dengan nilai 0,32 di wilayah hulu Q1 (Banjar Saresede) dengan kondisi baik menjadi kondisi cemar berat di wilayah tengah Q6 (Banjar Sema) dengan nilai 10,96 dan akhirnya di wilayah hilir Q7-Q8 tercemar ringan. 


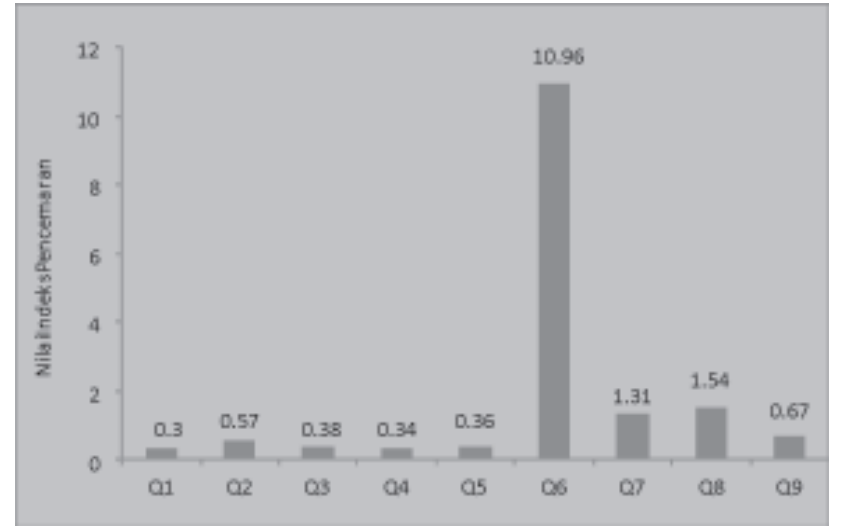

Gambar 1. Nilai Indeks Pencemar Baku Mutu Air Kelas I

Keterangan:

$\begin{array}{lll}\text { Q1 }=\text { Br. Saresede } & \text { Q4 }=\text { Br. Bukit } & \text { Q7 }=B r . \text { Bona Kaja } \\ \text { Q2 }=B r . \text { Penaka } & \text { Q5 }=B r \text {. Tiapi } & \text { Q8 }=B r . \text { Penulisan } \\ \text { Q3 }=B r \text {. Tegalsuci } & \text { Q6 }=B r \text {. Sema } & \text { Q9 }=B r . \text { Cucukan }\end{array}$

Status mutu air pada wilayah hulu menunjukan kondisi baik, karena adanya perkebunan, pertanian, belum ada pemukiman atau aktivitas manusia, industri serta peternakan yang mempengaruhi air sungai.

Pada wilayah hilir Q7 (Banjar Bona Kaja) hingga Q8 (Banjar Penulisan) menunjukkan cemar ringan yang nilai BOD, COD tidak melampaui baku mutu yang ditetapkan karena adanya lebih banyak pertanian, jauh dari pemukiman penduduk dan sumber mata air baru. Pada wilayah hilir lokasi Q9 (Banjar Cucukan) kondisi air kembali baik berdasarkan parameter konsentrasi BOD, COD, fosfat, fecal dan total coliform dibawah baku mutu air yang ditetapkan. Kualitas air yang baik karena bahan pencemar yang berasal dari aktivitas manusia yaitu pemukiman, pariwisata, industri berkurang, adanya sumber mata air baru dan terjadinya pemurnian air (self purification) oleh kondisi fisik sungai.

Hal ini menjadikan kualitas air Sungai Pakerisan di tengah tidak dapat dimanfaatkan sesuai dengan peruntukan air kelas I yaitu air yang dapat digunakan sebagai sarana/prasarana rekreasi air, pembudidayaan ikan air tawar, peternakan, air untuk mengairi pertanaman, dan atau peruntukan lain yang mempersyaratkan mutu air yang sama dengan kegunaan tersebut. Diperlukan pengendalian pencemaran air Sungai Pakerisan agar dapat dimanfaatkan dan menjaga agar kualitas air Sungai Pakerisan tetap sesuai dengan mutu air sasaran yaitu kriteria mutu air kelas I menurut Peraturan Gubernur No. 08 Tahun 2007 Provinsi Bali.

Sebagaimana sungai-sungai lainnya, hasil penelitian indeks pencemaran Tukad Saba terhadap baku mutu air kelas I tergolong tercemar ringan (Susanti, 2015). Hasil penelitian Sungai Telaga Waja terhadap indeks pencemarannya tergolong tercemar berat (Susila, 2012).

\section{SIMPULAN DAN SARAN}

\subsection{Simpulan}

Berdasarkan atas pembahasan di atas dapat disampaikan simpulan sebagai berikut:

a. Kualitas air Sungai Pakerisan di wilayah hulu dibawah baku mutu air kelas I, di wilayah tengah ditunjukkan dengan tingginya fecal coliform mencapai $640 \mathrm{jml} / 100 \mathrm{ml}$ dan total coliform mencapai $1100 \mathrm{jml} / 100 \mathrm{ml}$ melampaui baku mutu air kelas I. Konsentrasi BOD 0,8 mg/ 1-5,29 mg/l melebihi baku mutu air kelas I yaitu $>2 \mathrm{mg} / \mathrm{l}$. Konsentrasi COD $2 \mathrm{mg} / \mathrm{l}-13 \mathrm{mg} / \mathrm{l}$ melebihi baku mutu air kelas I yaitu $>10 \mathrm{mg} / \mathrm{l}$. Konsentrasi DO yaitu 3,88 mg/l-6,9 mg/l kurang dari kadar minimum baku mutu air kelas I yaitu $<6 \mathrm{mg} / \mathrm{l}$ dan fosfat konsentrasinya $0,07 \mathrm{mg} / \mathrm{l}$ $0,33 \mathrm{mg} / \mathrm{l}$ melebihi baku mutu air kelas I yaitu $>0,2 \mathrm{mg} / \mathrm{l}$. Di wilayah hilir konsentrasi BOD $2,41 \mathrm{mg} / \mathrm{l}-2,78 \mathrm{mg} / \mathrm{l}$, fosfat konsentrasinya 0,29 $\mathrm{mg} / \mathrm{l}-0,33 \mathrm{mg} / \mathrm{l}$ dan fecal coliform mencapai 110 $\mathrm{jml} / 100 \mathrm{ml}-230 \mathrm{jml} / 100 \mathrm{ml}$ melebihi baku mutu air kelas I.

b. Evaluasi indeks pencemaran terhadap baku mutu air kelas I pada wilayah hulu tergolong kondisi air baik karena belum adanya pencemaran, di tengah Banjar Sema Desa Bitra tercemar berat dan di hilir Banjar Cucukan kondisi air baik. Tingginya nilai indeks pencemaran karena terakumulasinya bahan pencemar dari aktivitas manusiasedangkan penurunannya karena di hilir aktivitas manusia berkurang, adanya sumber mata air baru dan terjadinya pemurnian air (self purification) oleh kondisi fisik sungai.

\subsection{Saran}

Berdasarkan atas hasil penelitian di atas dapat disampaikan saran sebagai berikut:

a) Kualitas air Sungai Pakerisan hendaknya dijaga kelestarian dan adanya pengawasan oleh pemerintah terhadap aktivitas yang terjadi dengan membuat kebijakan untuk menjaga di daerah aliran sungai (DAS) agar tidak membuang sampah atau kotoran ternak kesungai.

b) Pemilik usaha yang membuang limbahnya ke sungai hendaknya ikut dalam pemeliharaan kelestarian daerah aliran sungai Pakerisan dengan tidak membuang limbahnya ke sungai dan mendukung segala bentuk usaha dalam rangka peningkatan kualitas air dan lingkungan misalnya mempunyai tempat pengolahanlimbah.

c) Perlu dilakukan pemantauan kualitas air secara periodik untuk memperoleh gambaran kualitas air Sungai Pakerisan mengingat fungsinya sebagai daerah wisata serta daerah yang dilestarikan. 


\section{DAFTAR PUSTAKA}

Anhwange, B.A., E.B. Agbaji, and E.C. Gimba. 2012. "Impact Assessment of Human Activities and Seasonal Variation on River Benue, within Makurdi Metropolis". Journal of Science and Technology, 2. 248-254.

Ari Esta Kadek, Suarya dan Suastuti, 2016." Penentuan Status Mutu Air Tukad Yeh Poh dengan Metode Storet.” Jurnal Kimia 10(1): ISSN 1907-9850.

Azwir. 2006. Analisa Pencemaran Air Sungai Tapung Kiri oleh Limbah Industri Kelapa Sawit PT. Peputra Masterindo di Kabupaten Tanggerang. Tesis. Universitas Dipenogoro, Semarang.

Badan Pusat Daerah Aliran Sungai (BPDAS) Unda Anyar, 2015. Data DAS Pekerisan, 2005. Denpasar.

Blume, K.K., J.C. Macedo, A. Meneguzzi, L.B. Silva, D.M. Quevedo, and M.A.S. Rodrigues. 2010. "Water Quality Assessment of the Sinos River, Southern Brazil". Journal of Biology, 70. 11851193.

Effendi, H. 2003. Telaah Kualitas Bagi Pengelolaan Sumber Daya dan Lingkungan Perairan. Yogyakarta : Kanisius

Kristanto, P., 2002, Ekologi Industri, Penerbit Andi, Yogyakarta.

Pemerintah Provinsi Bali. 2007. Peraturan Gubernur Bali Nomor 8 Tahun 2007 tentang Baku Mutu Lingkungan dan Kriteria Baku Kerusakan Lingkungan Hidup.

Prihartanto dan Budiman, E.B. 2007. Sistem Informasi Pemantauan Dinamika sungai Siak. Alami, Vol. 12 Nomor 1 Tahun 2007 : 52-60.

PutriDwi, N.A., Afdal, Dwi Puryanti, 2014. Profil Pencemaran Air Sungai Siak Kota Pekanbaru Dari Tinjauan Fisis Dan Kimia. Jurnal Fisika Unand Vol. 3, No. 3, Juli 2014, ISSN 2302-8491.

Rahayu, S., dan Tontowi. 2009. "Penelitian Kualitas Air Bengawan Solo Pada Saat Musim Kemarau". Jurnal Sumber Daya Air, 5. 127-136.

Rai, I.N. dan M. Adnyana. 2011. Persaingan Pemanfaatan Lahan dan Air, Perspektif
Keberlanjutan Pertanian dan Kelestarian Lingkungan Udayana University Press.

Rai, I.N,S. Shoba, N. Shchegolkova, R. Dzhamalov, E. Venitsianov, I.G.N. Santosa, G.M. Adnyana, I.N. Sunarta, and I.K. Suada. 2015. Analysis of the Specifics of Water Resources Management in Regions Rapidly Growing Population under Different Climate Conditions: Case Study of Bali Island and the Moscow Regional. Journal of Water Resources. ISSN 0097-8078, Vol. 42, No. 5, pp. 735-746

Salmin. 2005. "Oksigen Terlarut (DO) dan Kebutuhan Oksigen Biologi (BOD) sebagai Salah Satu Indikator Untuk Menentukan Kualitas Perairan”. Jurnal Oseana, 30. 21-26

Suharto.Ign. (2011). Limbah Kimia dalam Pencemaran Air dan Udara. Yogyakarta : CV. Andi Offset.

Sutriati, A. 2011. "Penilaian Kualitas Air Sungai dan Potensi Pemanfaatannya (Studi Kasus Sungai Cimanuk)". Jurnal Sumber Daya Air, 7. 61-76.

Susanti, D. 2015. Identifikasi Sumber Pencemar Dan Analisis Kualitas Air Tukad Saba Propinsi Bali. Tesis. Program Pasca Sarjana Universitas Udayana, Denpasar.

Susila D, K. G, I. W. Sandi Adnyana, I. W. Budiarsa Suyasa, 2012. Studi Kualitas Air Sungai Telaga Waja Kabupaten Karangasem. Ecotrophic. Volume 7 Nomor 1 Tahun 2012. Hal 47-53

Wardhana, W.A, 2004. Dampak Pencemaran Lingkungan, Penerbit Andi, Yogyakarta.

Wiwoho, 2005, Model Identifikasi Daya Tampung Beban Cemaran Sungai Dengan QUAL2E. Tesis. Universitas Diponegoro. Semarang.

Yudo, S. 2010. "Kondisi Kualitas Air Sungai Ciliwung di Wilayah DKI Jakarta ditinjau dari Parameter Organik, Amoniak, Fosfat, Deterjen dan Bakteri Coli”. Jurnal Akuakultur Indonesia, 6. 34-42.

Yuliastuti, E. 2011. Kajian Kualitas Air Sungai Ngringo Karanganyar dalam Upaya Pengendalian Pencemaran Air. Tesis. Program Pascasarjana Universitas Diponegoro, Semarang. 